against this hypothesis is that, as in all new stars, the dark absorption bands are always on the violet side, and the bright radiation bands displaced towards the red; this implies that the former always move towards and the latter away from the sun, which, as he says, is highly improbable. M. Belopolsky does not consider the displacement of the bright lines towards the red end of the spectrum real at all, but only illusionary, in consequence of their unsymmetrical appearance. This unsymmetrical appearance is due, as he suggests, to the absorption bands, which lie nearer to the violet edges of the bright bands. In fact, he says, "streng gesagt existeren keine Ränder der Emissions-Banden," but that they merge into the continuous spectrum; it is only the existence of absorption bands which gives them their sharp edges on the violet side.

Another point which M. Bolopolsky dwells upon at some length is the apparent peculiarities in the behaviour of the intensities of some of the hydrogen and cleveite gas lines, and he is inclined to attribute these interchanges of intensity to actual changes of the lines themselves. Other observers have been more inclined to explain such apparent abnormal features by assuming that a neighbouring line of other origin was becoming bright, while the original line was on the wane. Thus, for instance, when the hydrogen spectrum of the Nova was dimming very considerably and the lines were all weak, one of the hydrogen lines, $\mathrm{H} \epsilon$, on the other hand, was becoming stronger. Since the weakening of the hydrogen lines was accompanied by a strengthening of the nebular lines, it was fair to assume that at, or close to, the position of $\mathrm{H} \epsilon$ a new line of unknown origin had made its appearance, especially if. it were of a similar nature to the nebular lines.

Enough, perhaps, has been said to indicate the general lines M. Belopolsky has followed. There are, however, many other points, such as the individual structure of the bright bands (M. Belopolsky has divided $\mathrm{H} \gamma$ into twenty-four and $\mathrm{H} \delta$ into twenty-eight parts), to which reference might be made, but these must be left to those readers who will read the original. Four plates accompany the text, the first two giving in diagrammatic form the intensity curves of the hydrogen bands, and the rest reproductions of the spectra of the Nova, with the terrestrial comparison spectra on different dates. It seems a pity that the latter are so very narrow that it is difficult, even with the aid of a lens, to identify more than the very general features, while one can assume that the originals were full of detail.

WiLliam J. S. Lockyer.

\section{THE BRITISH ANTARCTIC EXPEDITION.}

$T$ HE first news of the British Antarctic Expedition 1 since the departure of the Discovery from New Zealand in December, I90I, has been brought by the relief vessel Morning, commanded by Captain Colbeck, which arrived at Lyttelton on March 25. Captain Colbeck found the Discovery in MacMurdo Bay (Victoria Land) on January 23, I902; all was well on board and only one serious casualty had occurred-the loss of a seaman named Vince, who fell down an ice-slope into the sea and was drowned. Commander Scott's official report of the voyage of the Discovery up to the time of meeting with the Morning has been telegraphed home by Reuter, and is as follows :-

The Discovery entered the ice pack on January 23, I902, in latitude $67^{\circ}$ south. Cape Adare was reached on January 9 , but there a heavy gale and ice delayed the expedition, which did not reach Wood Bay until January 18. A landing was effected on January 20 in an excellent harbour situated in latitude $76^{\circ} 30^{\prime}$ south. A record of the voyage was deposited at Cape Crozier on January 22. The Discovery then proceeded along the barrier within a few cables' length, examining the edge and making repeated soundings. In longitude $165^{\circ}$ the barrier altered its character and trended northward. Sounding here showed that the Discovery was in shallow water. From the edge of the barrier high snow slopes rose to an extensive heavily glaciated land with occasional bare precipitous peaks. The expedition followed the coast line as far as latitude $76^{\circ}$, longitude $15^{\circ} 30^{\prime}$.

The heavy pack formation of the young ice caused the expedition to seek winter quarters in Victoria Land.

On February 3 the Discovery entered an inlet in the barrier in longitude $174^{\circ}$. A balloon was sent up, and a sledge party examined the land as far as latitude $78^{\circ} 50^{\prime}$. Near Mounts Erebus and Terror, at the southern extremity of an island, excellent winter quarters were found. The expedition next observed the coast of Victoria Land, extending as far as a conspicuous cape in latitude $78^{\circ} 50^{\prime}$. It was found that mountains do not exist here. Huts for living and for making magnetic observations were erected, and the expedition prepared for wintering. The weather was boisterous, but a reconnaissance of sledge parties was sent out, during which the seaman Vince lost his life, the remainder of the party narrowly escaping a similar fate. The ship was frozen in on March 24. The expedition passed a comfortable winter in well sheltered quarters. The lowest recorded temperature was $62^{\circ}$ below zero.

The sledging was begun on September 2, parties being sent out in all directions. Lieutenant Royds Mr. Skelton and party established a "record" in an expedition to Mount Terror, travelling over the barrier under severe sleighing conditions, with a temperature of $5^{\circ}$ below zero.

Commander Scott, Dr. Wilson, and Lieutenant Shackleton travelled ninety-four miles to the south, reaching land in latitude $80^{\circ} 17^{\prime}$ south, longitude $163^{\circ}$ west, and establishing a world's "record" for the farthest point south. "The journey was accomplished under trying conditions. The dogs all died, and the three men had to drag the sledges back to the ship. Lieutenant Shackleton almost died from exposure, but he has now quite recovered. The party found that ranges of high mountains continue through Victoria Land. At the meridian of $160^{\circ}$ foothills much resembling the Admiralty Range were discovered.

The ice barrier is presumably afloat. It continues horizontal, and is slowly fed from the land ice. Mountains 10,000 feet to 12,000 feet high were seen in latitude $82^{\circ}$ south, the coastline continuing at least as far as $83^{\circ} 20^{\prime}$ nearly due south. A party ascending a glacier on the mainland found a new range of mountains. At a height of 9000 feet a level plain was reached, which was unbroken to the west as far as the horizon.

The scientific work of the expedition includes a rich collection of marine fauna, of which a large proportion are new species. Sea and magnetic observations were taken, as well as seismographic records and pendulum observations. A large collection of skins and skeletons of southern seals and sea birds has been made. A number of excellent photographs have been taken, and careful meteorological observations were made. Extensive quartz and grit accumulations were found horizontally bedded in volcanic rocks. Lava flows were found in the frequently recurring plutonic rock which forms the basement of the mountains.

Before the arrival of the Morning the Discovery had experienced some privation owing to part of the supplies having gone bad. This accounted for the death of all the dogs. She was revictualled from the Morning, however, and the explorers are now in a position to spend a comfortable winter.

As the Discovery left Port Chalmers on December 24, I901, and reached Cape Adare on January 9, I902, the statement that she entered the pack ice on January 23 is obviously an error; the correct reading is probably " January $2-3$. ."

In addition to the above, the following telegrams have been transmitted by Reuter, under dates March 26,27 , and 28 :-

Captain Colbeck, of the Morning, said in the course of an interview that he thought the chances of the Discovery being free this season were doubtful.

Nine of the Discovery's seamen, who are tired of the No. 1744, voL. 67] 
work, have returned on board the Morning. Lieutenant Mulock has replaced Lieutenant Shackleton, who is invalided.

The sledge journey of Captain Scott, Dr. Wilson, and Lieutenant Shackleton, which resulted in the farthest pòint south being reached, took ninety-four days.

After the explorers had left a depôt which had been previously established sixty miles south of the ship, the snow became soft, and it was almost impossible to drag the sledges along. Half of the sledges had to be hauled five miles, and then the party returned and brought up the remainder, each five miles covered thus involving fifteen miles of travelling. This relay work lasted twenty-nine days.

The explorers established a depôt in latitude $80^{\circ} 30^{\prime}$ south, and then discarded all superfluous gear, and set out on December is for a dash to the south. On January I they reached latitude $82^{\circ} 17^{\prime}$ south. The southernmost depôt was regained on January 15 , and the ship on February 3 .

Lieutenant Armitage, second in command, on a sledge journey which he made to the westward, and which lasted fifty-two days, attained an altitude of 9000 feet. The party descended an ice slide to a glacier 3000 feet below. At one point of the journey they slid a distance of 1300 feet in one minute ten seconds, hanging by straps to the backs of the sledges. On the return journey Lieutenant Armitage fell into a crevasse and hung thirty feet below the surface. If he had not been harnessed to the others he would have fallen a depth of 2000 feet. In some places the sledges had to be lowered fifty feet, and then hauled up on the other side.

Captain Colbeck's opinion as to the Discovery's chances of getting clear of the ice is somewhat difficult to understand, as the Morning transferred a large quantity of stores to the Discovery, and had apparently no difficulty in getting out again, while it may be supposed that Commander Scott's decision to remain for another winter was made deliberately in pursuance of his original intention to spend two winters in the Antarctic regions. Further details will be awaited with great interest; the situation of the Discovery, as well as the statement in the last paragraph of the official report, emphasise the soundness of the policy which led to the dispatch of a relief vessel.

Even with the meagre information to hand, it is abundantly evident that the National Antarctic Expedition has already achieved a great success, both in the way of exploration and of scientific observation. The "record" for south latitude has been "broken"; by one hundred miles, and, what is more important, an unknown mountain region, extending to at least $83^{\circ} 20^{\prime} \mathrm{S}$. lat., has been discovered, suggesting, as Sir Clements Markham has remarked, that "land stretches to the Pole in a series of lofty mountains." The fact that the Discovery wintered at a point four hundred miles further south than any former expedition encourages the belief that her observations will be of real value to science-solving some of the crucial problems of terrestrial physics. Even greater results may be expected from the work still to be done, for Commander Scott and his comrades have the experience of one successful year to help them.

The success of the British expedition makes us look forward with the more interest to news from the German and Swedish expeditions, which are working in the "Weddell" and "Enderby" quadrants, and from which we may hear at any time. The Scottish Antarctic expedition will probably not be heard from for a year, as the Scotia only left the Falkland Islands on January 22, I903, and Mr. Bruce, who is in command, has materially altered his plans, as appears from the following letter which he has sent to Reuter's Agency :-

"In a few hours we take our departure for the south. Contrary to my previous intention, I am going to winter the ship if we find a suitable winter harbour, for, on account of the lateness of the season, there will not be time to set up a separate house and set the ship free. We had a most successful passage south, having accomplished the voyage in fifty-nine days, in contrast to ninety-two days that we took in the Balaena in 1892. Systematic hydrometer observations and temperature observations of the surface of the sea from $30^{\circ} \mathrm{N}$. have been taken, and those of the River Plate should prove of exceptional interest, since there are most remarkable and rapid changes both in density and temperature associated with strong currents. We have inspected and set up the meteorological station at Cape Pembroke, which should be as good as any in the Southern Hemisphere. This should form a very important subAntarctic station. We have sufficient funds to enable us to do this one year's work in the south. Now that we are on a solid basis it would be a great pity to come home before our work is really complete. A second winter, during which the ship could be kept going free, as well as the station, would be most valuable."

\section{NOTES.}

THE presidents of the sections of the British Association, for the meeting to be opened at Southport on September 9, are as follows:-Mathematical and Physical Science, Mr. C. V. Boys, F.R.S. (Chairman of Department for Astronomy and Meteorology, Dr. W. N. Shaw, F.R.S.); Chemistry, Prof. W. N. Hartley, F.R.S.; Geology, Prof W. W. Watts; Zoology, Prof. S. J. Hickson, F.R.S. ; Geography, Captain Ettrick W. Creak, C.B., F.R.S. ; Economic Science and Statistics, Mr. E. W. Brabrook, C.B.; Engineering, Mr. C. Hawksley; Anthropology, Prof. J. Symington; Botany, Mr. A. C. Seward, F.R.S. ; Educational Science, Sir William de W. Abney, K.C.B., F.R.S. On Friday, September II, a discourse on "Man as Artist and Sportsman in the Palæolithic Period" will be delivered by Dr. Robert Munro, and on Monday, September 14, Dr. Arthur Rowe will lecture on "The Old Chalk Sea, and some of its Teachings."

THE Times of Monday contained in its latest intelligence columns two telegrams from the United States, one dated March 28 and the other March 29, both of which had been transmitted "By Marconigraph." This starts, as the Times says in a leader, a lay-by-day transmission of news between the New and the Old World, undertaken on a contract basis, and thus distinctly marks a step forward in the development of wireless telegraphy. Mr. Cuthbert Hall stated to a representative of the Westminster Gazette that until the Post Office has granted the land connection for which the Wireless Co. ask (which has been granted in Canada and the United States), it is impossible to extend generally to the public and the Press the facilities afforded to the Times. Nevertheless, Transatlantic wireless telegraphy may now be considered on a practical commercial footing, since it is evident that the Marconi Co., and the Times also, feel confident of its trustworthiness if they make it the basis of an arrangement of this kind. We offer our sincere congratulations to Mr. Marconi on this advance. We have frequently commented in these columns on the extreme rapidity with which the practical development of wireless telegraphy has progressed in Mr. Marconi's hands; the present occasion affords another instance in point. There is pleasure in the remembrance of the part which pure science has played in leading to this development.

THE following have been elected fellows of the British Academy :-Dr. B. Bosanquet, Prof. E. G. Browne, Mr. Arthur Cohen, K.C., Mr. F. C. Conybeare, Prof. F. Y. Edgeworth, Dr. C. H. Firth, Prof. A. Campbell Fraser, Sir Edward Fry, Dr. F. J. Furnivall, Prof. P. Gardner, Dr. Henry Jackson, Dr. M. R. James, Dr. F. G. Kenyon,

NO. 1744 , vOL. 67$]$ 